Rev. Latino-Am. Enfermagem

2016;24:e2750

DOI: $10.1590 / 1518-8345.0775 .2750$

www.eerp.usp.br/rlae

\title{
Risk Factors for premature birth in a hospital ${ }^{1}$
}

\author{
Margarita E. Ahumada-Barrios ${ }^{2}$ \\ German F. Alvarado ${ }^{3}$
}

\begin{abstract}
Objective: to determine the risk factors for premature birth. Methods: retrospective case-control study of 600 pregnant women assisted in a hospital, with 298 pregnant women in the case group (who gave birth prematurely <37 weeks) and 302 pregnant women who gave birth to a full-term newborn in the control group. Stata software version 12.2 was used. The Chi-square test was used in bivariate analysis and logistic regression was used in multivariate analysis, from which Odds Ratios (OR) and Confidence Intervals (CI) of 95\% were derived. Results: risk factors associated with premature birth were current twin pregnancy (adjusted $\mathrm{OR}=2.4 ; \mathrm{p}=$ 0.02 ), inadequate prenatal care ( $<6$ controls) (adjusted $\mathrm{OR}=3.2 ; \mathrm{p}<0.001$ ), absent prenatal care (adjusted $\mathrm{OR}=3.0 ; \mathrm{p}<0.001$ ), history of premature birth (adjusted $\mathrm{OR}=3.7 ; \mathrm{p}<0.001$ ) and preeclampsia (adjusted $\mathrm{OR}=1.9 ; \mathrm{p}=0.005$ ). Conclusion: history of premature birth, preeclampsia, not receiving prenatal care and receiving inadequate prenatal care were risk factors for premature birth.
\end{abstract}

Descriptors: Prematurity; Pregnancy Gemelar; Preeclampsia; Preterm Birth.

\footnotetext{
${ }^{1}$ Article extracted from undergraduate thesis "Risk Factors for Premature Birth in a Hospital of North Lima" presented to Facultad de Ciencias de la Salud, Universidad Católica Sedes Sapientiae, Lima, Peru.

2 RN, Assistant Professor, Facultad de Ciencias de la Salud. Universidad Católica Sedes Sapientiae. Lima, Peru. Sanidad de la Escuela de Supervivencia en el Mar. Fuerza Aérea del Perú, Lima, Peru.

${ }^{3}$ PhD, Associate Professor, Facultad de Ciencias de la Salud. Universidad Católica Sedes Sapientiae. Lima, Peru. Associate Professor, Facultad de Salud Pública y Administración "CVL". Universidad Peruana Cayetano Heredia, Lima, Peru.
}

Ahumada-Barrios ME, Alvarado, GF. Risk Factors for premature birth in a hospital. Rev. Latino-Am. Enfermagem. 2016;24:e2750. [Access $\left.\right|_{\text {month }} \frac{1}{\text { day }} \frac{1}{\text { year }}$ ]; Available in: org/10.1590/1518-8345.0775.2750

:

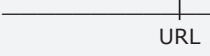

DOI: http://dx.doi. 


\section{Introduction}

World Health Organization (WHO) defined premature birth or preterm birth as the birth occurring after 20 weeks and before 37 weeks of gestation ${ }^{(1)}$. Premature birth is a syndrome associated with neonatal morbidity, which has adverse consequences for longterm health(2) and the sum of complications during the lives of premature infants causes high neonatal mortality rates $^{(3)}$.

Premature birth has been associated with several factors, such as history of preterm birth ${ }^{(4-7)}$, anemia(8-9), high catecholamine levels in the maternal urine ${ }^{(10)}$, tobacco consumption(11-12), premature rupture of membranes (PROM) $)^{(5,13)}$, high blood pressure $(\mathrm{HBP})^{(14)}$, vaginal bleeding ${ }^{(5)}$, intergestational intervals $\leq 1$ year ${ }^{(5)}$, urinary tract infection (UTI) $)^{(5-6,15)}$, lack of prenatal care(13), inadequate prenatal care ${ }^{(13,16)}$, maternal age

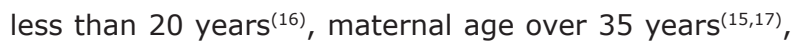
oligohydramnios(6), history of induced abortion(18-20), preeclampsia( ${ }^{(6-7,13,21)}$, twin pregnancy ${ }^{(6-7,13)}$, advanced maternal age ${ }^{(6)}$.

Moreover, although there are several risk factors associated with premature birth, its etiology has not been fully determined ${ }^{(9,15)}$. There are studies on the subject in Latin America, and several of them show methodological limitations, so that this fact has prompted the need for carrying out this study in a hospital in North Lima and, thereby, contribute to the knowledge on this subject. The main objective of this study is to determine the risk factors for premature birth in a hospital in North Lima.

\section{Methods}

A retrospective unmatched case-control study was carried out with a sample of 600 babies born alive at the National Hospital Sergio E. Bernales (NHSEB), located in the municipality of Lima, Peru. They were born between January 1 and December 31, 2011, with which two groups were formed:
- A case group (premature babies), consisted of 298 newborns with gestational age (GA) less than 37 weeks at birth, out of a total of 422 premature babies born during the study period. Here, 34 medical records were excluded due to incomplete data (gestational age, parity, number of prenatal controls and hemoglobin) and 90 medical records that were not found in the Archive Department of the NHSEB (as shown in Figure 1). A survey was performed for this group, considering all medical records (of mothers who gave birth prematurely in 2011), which were likely to be found at the Archive Department of the NHSEB.

- A group of unmatched controls (full-term newborns), composed of 302 newborns with a GA greater than or equal to 37 weeks and less than or equal to 42 weeks, out of a total of 342 full-term newborns, selected through simple random sampling during the study period, from a total of non-cases $(N=5020)$. Here, 12 medical records were excluded due to incomplete data (gestational age, parity, number of prenatal controls and hemoglobin) and 28 medical records that were not found in the Archive Department of the NHSB. Simple random sampling was performed using RANDBETWEEN Function( $n, N)$ in Excel.

It is worth mentioning that 268 medical records belonging to mothers who gave birth to a post term newborn were excluded. To determine the GA, it was taken into account the age indicated in the record book of children born in 2011, of the Neonatology service of the NHSEB, confirmed by physical examination of the newborn or Capurro method, which was registered in each medical record. 


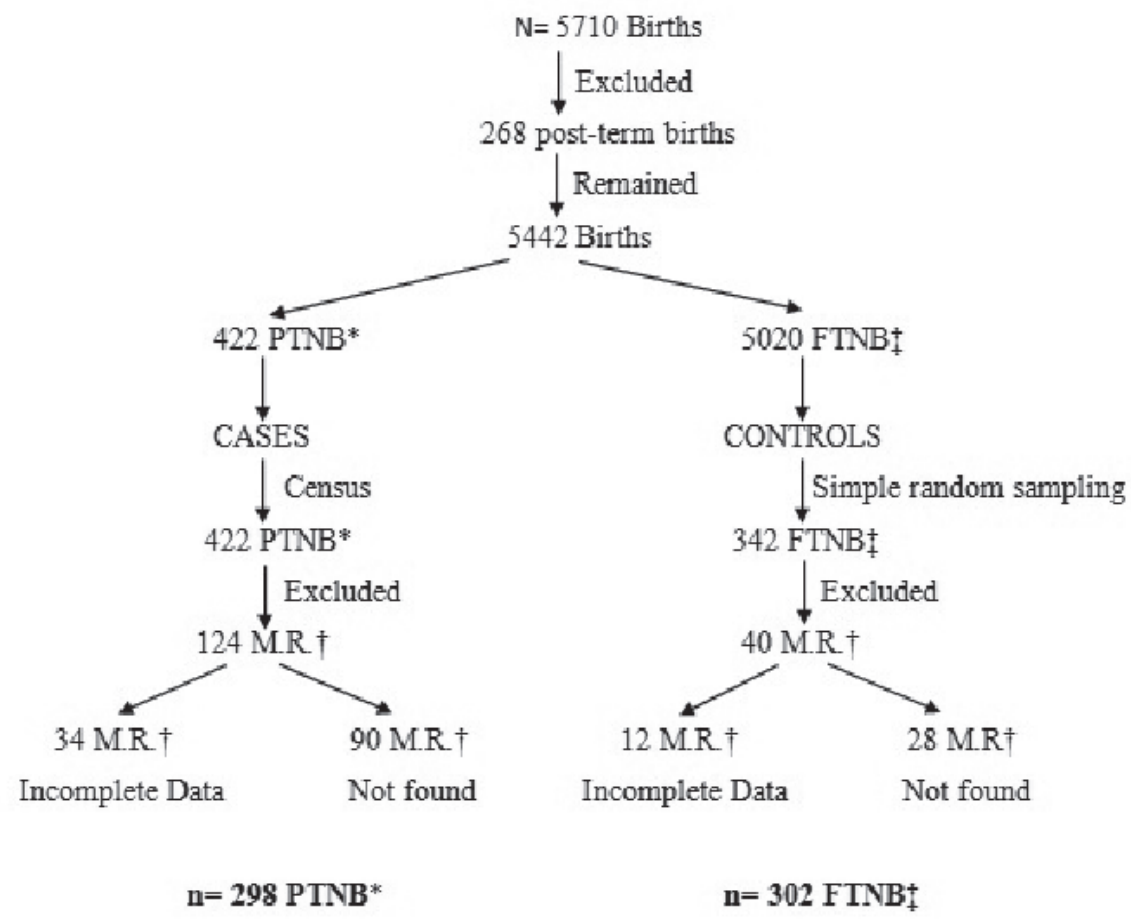

\section{*PTNB Preterm Newborn \\ $\dagger \mathrm{M} \cdot \mathbf{R}=$ Medical Record \\ †FTNB= Full-term newborn}

Figure 1 - Flowchart of participation

The following data were obtained from medical records: maternal age, marital status, gestational age, number of prenatal controls (appropriate, inappropriate and absent)(22), number of abortions, number of births (vaginal and cesarean section), history of premature birth, anemia ( $<11 \mathrm{mg} / \mathrm{dL}$ ), UTI, PROM, preeclampsia, oligohydramnios, smoking (active smoking mothers), current twin pregnancy and vaginal bleeding (bleeding during the first and second trimester of pregnancy). These data were entered into a Microsoft Excel ${ }^{\circledR} 2010$ database.

Stata version 12.2 was used for data processing. In univariate analysis, proportions and measures of central tendency and dispersion were calculated according to the variable type.

In bivariate analysis, the Chi-square test was used to compare two categorical variables, based on previous specific assumptions, producing crude Odds Ratios and 95\% Confidence Intervals (CI); and logistic regression was used in multivariable analysis, considering all the variables with $\mathrm{p}<0.20$ in the bivariate analysis. Adjusted Odds Ratios (OR) and 95\% Confidence Intervals (CI) were estimated and Akaike and Bayesian information criteria were used for modelling; model goodness of fit was checked using the Hosmer-Lemeshow test. It was considered a level of significance $p<0.05$.

Ethics Committee of the University
and the Hospital approved the study.

\section{Results}

During the study period, 5,710 births were registered in the National Hospital Sergio E. Bernales, where the prevalence of premature birth in the population was $7.4 \%$. It was observed that the average age was 26.2 years, in a sample of 600 pregnant women.

According to Table 1 (bivariate analysis), the factors considered statistically significant for prematurity were: previous abortion ( $p=0.04$ ), inadequate ( $<6$ controls) or lack of prenatal care (no control) $(p<0.001)$, history of premature birth $(p<0.001)$, preeclampsia $(p=$ $<.001)$ and bleeding ( $p=0.004)$.

As for the other factors investigated (age, parity, current twin pregnancy, anemia, UTI, PROM, oligohydramnios and smoking), no significant differences were found between the two groups. 
Table 1 - Bivariate analysis in pregnant women for current premature birth in a Hospital of North Lima, Peru, 2011

\begin{tabular}{|c|c|c|c|}
\hline Risk factor & $\begin{array}{l}\text { Cases } \\
\mathrm{n}(\%)\end{array}$ & $\begin{array}{c}\begin{array}{c}\text { Controls } \\
\mathrm{n}(\%)\end{array} \\
\end{array}$ & $p$-value \\
\hline \multicolumn{4}{|l|}{ Age (years) } \\
\hline mean+- S.D. & $25.7 \pm 6.8$ & $26.6 \pm 7.3$ & 0.15 \\
\hline \multicolumn{4}{|l|}{ Parity } \\
\hline 0 children & $97(32.6)$ & $107(35.4)$ & 0.54 \\
\hline $1-2$ children & $155(52.0)$ & $157(52.0)$ & \\
\hline$\geq 3$ children & $46(15.4)$ & $38(12.6)$ & \\
\hline \multicolumn{4}{|c|}{ Current twin pregnancy } \\
\hline No & $276(92.6)$ & $288(95.4)$ & 0.16 \\
\hline Yes & $22(7.4)$ & $14(4.6)$ & \\
\hline \multicolumn{4}{|c|}{ Previous abortion } \\
\hline No & $194(65.1)$ & $172(57.0)$ & $0.04^{*}$ \\
\hline Yes & $104(34.9)$ & $130(43.0)$ & \\
\hline \multicolumn{4}{|l|}{$\mathrm{PNC}^{\dagger}$} \\
\hline Adequate $(>=6)$ & $129(43.3)$ & $213(70.5)$ & $<0.001 \ddagger$ \\
\hline Inadequate $(<6)$ & $122(40.9)$ & $64(21.2)$ & \\
\hline Absent $(=0)$ & $47(15.8)$ & 25 (8.3) & \\
\hline \multicolumn{4}{|c|}{ History of premature birth } \\
\hline No & $191(64.1)$ & $260(86.1)$ & $<0.001 \ddagger$ \\
\hline Yes & $107(35.9)$ & $42(13.9)$ & \\
\hline \multicolumn{4}{|l|}{ Anemia } \\
\hline No & $101(33.9)$ & $126(41.7)$ & 0.05 \\
\hline Yes & $197(66.1)$ & $176(58.3)$ & \\
\hline \multicolumn{4}{|l|}{ UTI\$ } \\
\hline No & $168(56.4)$ & $177(58.6)$ & 0.60 \\
\hline Yes & $130(43.6)$ & $125(41.4)$ & \\
\hline \multicolumn{4}{|l|}{ PROM"I } \\
\hline No & $239(80.2)$ & $232(76.8)$ & 0.30 \\
\hline Yes & $59(19.8)$ & $70(23.2)$ & \\
\hline \multicolumn{4}{|l|}{ Preeclampsia } \\
\hline No & $227(76.2)$ & $263(87.1)$ & $<0.001 \ddagger$ \\
\hline Yes & $71(23.8)$ & $39(12.9)$ & \\
\hline \multicolumn{4}{|c|}{ Oligohydramnios } \\
\hline No & $266(89.3)$ & $282(93.4)$ & 0.10 \\
\hline Yes & $32(10.7)$ & $20(6.6)$ & \\
\hline \multicolumn{4}{|l|}{ Smoking } \\
\hline No & $287(96.3)$ & $295(97.7)$ & 0.30 \\
\hline Yes & $11(3.7)$ & $7 \quad(2.3)$ & \\
\hline \multicolumn{4}{|l|}{ Bleeding } \\
\hline No & $283(95.0)$ & $299(99.0)$ & $0.004 \ddagger$ \\
\hline Yes & $15(5.0)$ & $3(1.0)$ & \\
\hline
\end{tabular}

*p<0.05

$+\mathrm{PNC}=$ Prenatal care

$\neq \mathrm{p}<0.01$

$\S U T I=$ Urinary tract infection

||PROM $=$ Premature rupture of membranes 
Table 2 shows the results of multivariate analysis. The following factors emerged as statistically significant for premature birth: current twin pregnancy (adjusted $\mathrm{OR}=2.4 ; \mathrm{p}=0.02)$, inadequate prenatal care $(<6$ controls) (adjusted OR $=3.2 ; \mathrm{p}<0.001$ ), absent prenatal care (no control) (adjusted $O R=3.0 ; p<0.001$ ), history of premature birth (adjusted $O R=3.7 ; p<0.001$ ) and preeclampsia (adjusted $O R=1.9 ; p=0.005$ ).

Table 2 - Multivariate analysis in pregnant women for current premature birth in a Hospital of North Lima, Peru, 2011

\begin{tabular}{|c|c|c|c|}
\hline Risk factor & Crude OR $(95 \% \mathrm{Cl})$ & Adjusted OR $(95 \% \mathrm{Cl})^{*}$ & p-value ${ }^{*}$ \\
\hline Age (years) & $1.0(0.9-1.0)$ & $1.0(1.0-1.1)$ & $0.03 \dagger$ \\
\hline \multicolumn{4}{|l|}{ Parity } \\
\hline 0 children & 1.0 & - & \\
\hline $1-2$ children & $1.1(0.8-1.6)$ & & \\
\hline$\geq 3$ children & $1.3(0.8-2.2)$ & & \\
\hline \multicolumn{4}{|l|}{ Current twin pregnancy } \\
\hline No & 1.0 & 1.0 & \\
\hline Yes & $1.6(0.8-3.3)$ & $2.4(1.1-5.1)$ & $0.02 \dagger$ \\
\hline \multicolumn{4}{|l|}{ Previous abortions } \\
\hline No abortion & 1.0 & 1.0 & \\
\hline Abortion & $0.7(0.5-1.0)$ & $0.7(0.5-1.0)$ & 0.08 \\
\hline \multicolumn{4}{|l|}{$\mathrm{PNC}^{\ddagger}$} \\
\hline Normal $(>=6)$ & 1.0 & 1.0 & \\
\hline Inadequate $(<6)$ & $3.2(2.2-4.6)$ & $3.2(2.1-4.7)$ & $<0.001 \S$ \\
\hline Absent & $3.1(1.8-5.3)$ & $3.0(1.7-5.4)$ & $<0.001 \S$ \\
\hline \multicolumn{4}{|l|}{ History of premature birth } \\
\hline No & $1.0-$ & 1.0 & \\
\hline Yes & $3.5(2.3-5.2)$ & $3.7(2.3-5.8)$ & $<0.001 \S$ \\
\hline \multicolumn{4}{|l|}{ Anemia } \\
\hline No & 1.0 & 1.0 & \\
\hline Yes & $1.4(1.0-2.0)$ & $1.2(0.8-1.7)$ & 0.47 \\
\hline \multicolumn{4}{|l|}{ UTIII } \\
\hline No & $1.0-$ & - & \\
\hline Yes & $1.1(0.8-1.5)$ & & \\
\hline \multicolumn{4}{|l|}{ PROM } \\
\hline No & $1.0-$ & - & \\
\hline Yes & $0.8(0.6-1.2)$ & & \\
\hline \multicolumn{4}{|l|}{ Preeclampsia } \\
\hline No & 1.0 & 1.0 & \\
\hline Yes & $2.1(1.4-3.2)$ & $1.9(1.2-3.1)$ & $0.005 \S$ \\
\hline \multicolumn{4}{|l|}{ Oligohydramnios } \\
\hline No & 1.0 & 1.0 & \\
\hline Yes & $1.7(1.0-3.0)$ & $1.8(0.9-3.4)$ & 0.09 \\
\hline \multicolumn{4}{|l|}{ Smoking } \\
\hline No & 1.0 & - & \\
\hline Yes & $1.6(0.6-4.2)$ & & \\
\hline \multicolumn{4}{|l|}{ Bleeding } \\
\hline No & 1.0 & 1.0 & \\
\hline Yes & $5.3(1.5-18.4)$ & $3.0(0.8-11.5)$ & 0.11 \\
\hline
\end{tabular}

*From logistic regression

$+\mathrm{p}<0.05$

$\neq \mathrm{PNC}=$ Prenatal care

$\S \mathrm{p}<0.01$

| UTI = Urinary tract infection

IPROM= Premature rupture of membranes 


\section{Discussion}

The most important findings of this study are: a) the prevalence of premature birth was $7.4 \%$ and $b$ ) risk factors for prematurity were current twin pregnancy, history of premature birth, preeclampsia, inadequate prenatal care and lack of prenatal care.

Before starting further discussion, the main limitations shall be mentioned: the limitation regarding the sample is a possible selection bias, since 124 medical records were excluded from the cases group (34 medical records due to incomplete data and 90 medical records because they were not found in the Archive Department of the hospital). In the control group, 40 medical records were excluded (12 medical records due to incomplete data and 28 medical records that were not found in the Archive Department of the hospital). However, there is no evidence that the associations investigated are different in the samples not included in the cases and controls. Moreover, in the evaluation of the variables, it was not possible to measure the levels of catecholamines or antecedents of HBP, because this was a retrospective study and such data were not registered in the medical records.

This study has as strengths the retrospective and unmatched design type of cases and controls with appropriate statistical analysis. In addition, it shows a representative sample of the study population, since it was used a census in the cases group, whereas a simple random sampling was used in the control group.

On the other hand, this work is very important because there are scarce studies in Latin America on premature birth.

Amongst the factors investigated in this study, preeclampsia was a risk factor for premature birth ${ }^{(23)}$. According to the study of García et al., premature births were more frequent among pregnant women with preeclampsia ( $p<0.001, R R=5.5 ; 95 \%$ CI for RR: 3.7$7.1)^{(21)}$ Similarly, the study of Osorno and colleagues reported that women with preeclampsia have risk of premature birth between 1.4 and $1.9^{(6)}$. On the other hand, current twin pregnancy represents a risk factor for premature birth, which is corroborated by a Mexican study that reported that women with triple pregnancy are 40.7 times more likely to have a premature birth, whereas twin pregnancy has an increased probability of 12 times $^{(6)}$. These results were very similar to those of Gene Barrios, who reported that twin pregnancy is a risk factor for this multifactorial syndrome $(O R=15.1)$ (7), as demonstrated by Diaz, which also pointed out multiple pregnancy as a factor significantly associated with the occurrence of premature birth $(\mathrm{OR}=6.2 ; \mathrm{p}$ $<0.01)^{(13)}$.

As for the history of premature birth, this showed to be a risk factor for premature birth in a subsequent pregnancy, similar to the results reported by Gene Barrios, which also reported that prior premature birth is a risk factor for prematurity (OR $=3.4 ; 95 \%$ CI: $1.0-12.8)^{(7)}$. Additionally, a study conducted in Indonesia showed that history of premature birth is a factor associated with premature birth in rural areas ${ }^{(4)}$. Furthermore, in two studies carried out in Mexico, premature birth was also associated with subsequent premature births ${ }^{(5-6)}$, i.e. a previous premature birth increases the risk of a second birth under the same condition.

Another risk factor for premature birth was not receiving PNC or receiving an inadequate PNC, which is supported by the study of Sánchez and coworkers, who also indicated that the lack of prenatal care is related to prematurity, otherwise it would not be possible to diagnose complications of pregnancy and provide appropriate treatment ${ }^{(24)}$.

In addition, a study of Osorno and colleagues reported that the prevalence of prematurity is higher when there is less than 6 prenatal controls (OR: 1.7; 95\% CI: 1.6-2.0), whereas in women without any prenatal control, the risk is 2.3 times higher (OR: 2.3; 95\% CI: $2.0-2.8)^{(15)}$; ; data similar to those of a Mexican study that reported that an inadequate prenatal care increased the risk $(\mathrm{OR}=2.0 ; 95 \% \mathrm{CI}: 1.5-2.7)^{(16)}$. Finally, the study of Ouattara and colleagues reported that inadequate prenatal care is associated with prematurity (OR: $4.9 ; 95 \% \mathrm{CI}: 3.0-8.0)^{(13)}$.

It is known that premature birth remains one of the most common problems in the Peruvian perinatology despite medical advances, as verified in the study hospital in North Lima, where the prevalence of prematurity in 2011 was 7,4\% in every 100 births. This rate seems higher than the observed in previous years $(6.5 \%$ in every 100 births in 2010, and $6.6 \%$ in every 100 born in 2009) ${ }^{(25)}$, representing a challenge for physicians and neonatologist nurses in the prevention and care.

Therefore, this study is highly relevant to public health because the early detection and control of the risks mentioned above could result in a reduction in prematurity.

In future research, those interested in this subject are invited to conduct cohort studies, in which catecholamine levels could be measured. 


\section{Conclusions}

The prevalence of premature birth was $7.4 \%$. It was concluded that the risk factors for prematurity are not receiving prenatal care, receiving inadequate prenatal care, preeclampsia and history of premature birth.

\section{Acknowledgements}

To the authorities of HNSEB for their support for data collection and to Carlos Huayanay, BS for his support in the first draft of statistical analysis.

\section{References}

1. World Health Organization (WHO). Glossary on assisted reproductive terminology [en línea]. Ginebra; 2010 [accesado 24 Nov 2011]. Disponible en: http:// www.who.int/reproductivehealth/publications/ infertility/art_terminology_es.pdf

2. Tronnes H, Wilcox AJ, Lie RL, Markestad T, Moster D. Risk of cerebral palsy in relation to pregnancy disorders and preterm birth: a national cohort study. Dev Med Child Neurol. 2014;56(8):779-85.

3. Meza Martínez J. Factores maternos relacionados con el parto pretérmino y su repercusión en el neonato. Hospital Nacional Hipólito Unanue: 2002 -2006. Rev Peruana Obst Enferm. 2008;3(2):115-25.

4. Schwab FD, Zettler EK, Moh A, Schötzau A, Gross $U$, Günthert AR. Predictive factors for preterm delivery under rural conditions in post-tsunami Banda Aceh. J Perinat Med. 2015. [EPub ahead of print]

5. Morgan F, Cinco A, Douriet F, Báez J, Muñoz J, Osuna

I. Factores sociodemográficos y obstétricos asociados con nacimiento pretérmino. Ginecol Obstet Mex. 2010;78(2):105-7.

6. Ozorno L, Rupay G, Rodríguez J, Lavadores A, Dávila J, Echevarría M. Factores maternos relacionados con prematuridad. Ginecol Obstet Mex. 2008;76(9):526-36.

7. Genes V. Factores de riesgo asociados al parto pretérmino. Rev Nac Itaugua. 2012;4(2):8-14.

8. Scholl TO, Hediger ML, Fischer RL, Shearer JW. Anemia vs iron deficiency: increased risk of preterm delivery in a prospective study. Am J Clim Nutr. 2011;55(5):985-86.

9. Giacomin L, Leal M, Moya R. Anemia materna en el tercer trimestre de embarazo como factor de riesgo para parto pretérmino. Acta Med Costarric. 2009;51(1):3943.

10. Holzman C, Senagore P, Tian $Y$, Bullen B, Devos

$E$, Leece $C$ et al. Maternal catecholamine levels in midpregnancy and risk of preterm delivery. Am J Epidemiol. 2009;170(8):1018-9.

11. Wikstrom A, Cnattingius $S$, Galanti $M$, Kieler $H$, Stephansson O. Effect of Swedish snuff on preterm birth. BJOG. 2010;117(8):1007-8.

12. McCowan L, Dekker G, Chan E, Stewart A, Chappell $L$, Hunter $M$, et al. Spontaneous preterm birth and small for gestational age infants in women who stop smoking early in pregnancy: prospective cohort study. BMJ. 2009;338(1):1-6.

13. Ouattara A, Ouegraogo CM, Ouedraogo A, Lankoande J. Factors associated with preterm birth in an urban African environment: A case-control study at the University Teaching Hospital of Ouagadougou and Saint Camille Medical Center. Med Sante Trop. 2015. [Epub ahead of print].

14. Morisaki N, Togoobaatar G, Vogel JP, Souza JP, Rowland-Hogue $\mathrm{C}$, Jayaratne $\mathrm{K}$ et al. Risk factors for spontaneous and provider-initiated preterm delivery in high and low Human Development Index countries: a secondary analysis of the World Health Organization Multicountry Survey on Maternal and Newborn Health. BJOG. 2014;121 Suppl 1:101-9.

15. Rodríguez S, Ramos R, Hernández R. Factores de riesgo para la prematurez. Estudio de casos y controles. Ginecol Obstet Mex. 2013;81(9):499-503.

16. Pérez J, Panduro G, Quezada C. Factores maternos asociados con nacimiento pretérmino espontáneo versus pretérmino nacido por cesárea. Ginecol Obstet Mex. 2011;79(10):607-12.

17. Peña G, Barbato J. Asociación entre prematuridad y embarazadas en edad avanzada. Rev Obstet Ginecol Venez. 2007;67(1):15-22.

18. Hardy G, Benjamin A, Abenhaim H. Effects of Induced Abortions on Early Preterm Births and Adverse Perinatal Outcomes. JOGC. 2013;35(2):138-43.

19. Moreau C, Kaminski M, Ancel PY, Bouyer J, Escande $B$, Thiriez $G$, et al. Previous induced abortions and the risk of very preterm delivery: results of the EPIPAGE study. JOGC. 2005;112(4):430-7.

20. Hardy G, Benjamin A, Abenhaim, HA Effect of Induced Abortions on Early Preterm Births and Adverse Perinatal Outcomes. J Obstet Gynaecology Can. 2013;35(2):13843.

21. García R, Llera A, Pacheco A, Delgado M, González A. Resultados materno-perinatales de pacientes con preeclampsia. Rev Cubana Obstet Ginecol. 2012;38(4):467-77.

22. Arispe C, Salgado M, Tang G, Gonzáles C, Rojas L. Frecuencia de control prenatal inadecuado y de factores asociados a su concurrencia. Rev Med Hered. 2011;22(4):169-75. 
23. Contreras A, Soria C, Pince R, Clark I, Medina M. Preeclampsia: principal factor de riesgo materno para bajo peso del recién nacido pretérmino. Ginecol Obstet Mex. 2008;76(7):398-403.

24. Sánchez R, Pérez P, Vázquez F. Impacto del control prenatal en la morbilidad y mortalidad neonatal. Rev Med Inst Mex Seguro Soc.2005;43(5):377-80.

25. Hnseb.gob.pe: oficina de estadística e informática [en línea]. Lima: Hospital Nacional Sergio Edgardo Bernales; [accesado 14 Dic 2011]. Disponible en: http://www.hnseb.gob.pe/estadistica/estadistica_est. html

Copyright $\odot 2016$ Revista Latino-Americana de Enfermagem This is an Open Access article distributed under the terms of the Creative Commons (CC BY).

This license lets others distribute, remix, tweak, and build upon your work, even commercially, as long as they credit you for the original creation. This is the most accommodating of licenses offered. Recommended for maximum dissemination and use of licensed materials. 